\title{
Model Advance organizer dengan Pendekatan Humanistik: Upaya Meningkatkan Pemahaman Relasional Siswa SMK pada Materi Program Linear
}

\author{
Suwandi ${ }^{*}$, Endah Budiastuti ${ }^{2}$ \\ ${ }^{1}$ Manajemen, STIE Cirebon,Cirebon, Indonesia; wandimathstie@gmail.com ${ }^{1 *}$ \\ ${ }^{2}$ Akuntansi, STIE Cirebon,Cirebon, Indonesia; endah@gmail.com²
}

Info Artikel: Dikirim: 16 Oktober 2020; Direvisi: 15 Januari 2021; Diterima: 2 Maret 2021

Cara sitasi: Suwandi \& Budiastuti, E. (2021). Model Advance organizer dengan Pendekatan Humanistik: Upaya Meningkatkan Pemahaman Relasional Siswa SMK pada Materi Program Linear. JNPM (Jurnal Nasional Pendidikan Matematika) 5(1), 65-80.

\begin{abstract}
Abstrak. Perangkat pembelajaran merupakan salah satu alat untuk mencapai keberhasilan dalam proses belajar. Perangkat yang efektif mampu menumbuhkan motivasi dan keaktifan siswa dalam belajar sehingga perlu dikembangkan lebih lanjut. Penelitian ini merupakan penelitian pengembangan yang bertujuan untuk mengembangkan dan mendeskripsikan implementasi pembelajaran model advance organizer menggunakan pendekatan humanistik untuk meningkatkan kemampuan pemahaman relasional menggunakan alat yang efektif dan sederhana pada materi program linier Kelas $X$, desain pengembangan mengacu pengembangan yang di sampaikan Plomp yang dimodifikasi.Berdasarkan hasil validasi dan hasil uji coba diperoleh perangkat yang valid, implementasi pembelajaran praktis dan hasil uji coba diperoleh pembelajaran yang efektif, maka tujuan pengembangan perangkat tercapai.
\end{abstract}

Kata Kunci: Advance organizer, Pendekatan Humanistik, Pemahaman Relasional.

Abstract. Learning tools are one of the tools to achieve success in the learning process. Effective devices are able to foster motivation and student activity in learning so that it needs to be further developed. This research is a development research that aims to develop and describe the implementation of advanced organizer model learning using a humanistic approach to improve the ability of relational understanding using effective and simple tools on the Class X linear program material, the development design refers to the development conveyed by the modified Plomp. Based on the results of the validation and the results of the trial, a valid device was obtained, the implementation of practical learning and the test results obtained an effective learning, so the goal of developing the device was achieved.

Keywords: Advance organizer, Humanistic Approach, Relational Understanding.

\section{Pendahuluan}

Belajar adalah proses hubungan pada kelas, dimana siswa wajibterus berinteraksi dan secara bertahap mengubah tingkat bantuan mereka untuk membuat kemajuan lebih lanjut (Murata \& Fuson, 2006). Dalam usaha nya untuk mencapai kemajuan yang lebih lanjutdalam menguasai materi pembelajaran diperlukan hal yang mendasar yaitusiswa wajibmenguasai beberapa kemampuan dasar, kemudian siswa harus mampu menghubungkan pengetahuan baru yang telah diperolehnya dengan pengetahuan yang 
dimiliki sebelumnya (Corkill, 1992). Kemahiran belajar yang telah diperolehdalam proses belajar akan sangat menentukan berhasil tidaknya proses belajar selanjutnya. Guru diharapkan dapat memeriksa, mengingatkan, atau meningkatkan pengetahuan prasyarat sebelum mulai membahas topik bahasan baru. Dengan demikian, pengetahuan baru dapat dikombinasikan dan dikolaborasikan melalui pengetahuan yang sudah dipahami oleh siswasebelumnya yang lebih dikenal dengan pembelajaran bermakna. Tujuannya untuk menjelaskan, mengintegrasikan materi baru dan mengaitkannya dengan materi yang dipelajari sebelumnya (Kovalik \& Williams, 2011).

Skemp (1976) mengkategorikan kognisi menjadi dua, yaitu kognisi relasional dan kognisiinstrumental. Kognisi relasional diartikansebagai pemahaman untuk mengetahui yang harus dilakukan dan mengapa serta bagaimana hal tersebut dilakukan, sedangkan pemahaman instrumental diartikan sebagai mengetahui langkah dan aturan tanpa penjabaran alasan untuk apa dan bagaimana, dengan kata lain pemahaman instrumen diartikan bahwa anak didik mengetahui mekanisme atau langkah-langkah menyelesaikan masalah tanpa mengetahui mengapa mekanisme tersebut digunakan. Kinach, (2002) mengasumsikan pemahaman yang ditulis Skemp, (1976), bahwa pemahaman instrumen setingkat dengan pemahaman tingkat dasar, sedangkan kognisi relasional mencakup pemahaman konseptual, memecahkan masalah, dan pemahaman kognitif. Pemikiran relasional sangat bermanfaat dalam proses belajar matematika, karena banyak gagasan baru tentang matematika yang mengimplikasikan interaksi antara representatif bilangan yang tidak sama dan operasi bilangan serta objek matematika lainnya (Molina, Castro, \& Ambrose, 2005). Akibatnya, siswa yang mencoba memahami matematika melalui cara relasional akan mempresentasikan pola pikir mereka dengan membandingkan antara kesamaan dan perbedaan kompetensi baru yang dipahaminya, menggabungkan kompetensi baru dengan kompetensi yang dipahami untuk dikolaborasikan dan diterapkan dalam belajar (Kurniawan \& Rudhito, 2016).

Hal yang diungkap Jamal (2014) terkait tentang kesulitan dalam memahami konsep matematika yaitu siswa perlu terus diingatkan dan diberikan motivasi-motivasi oleh guru agar semangat belajar tumbuh, siswa kurang mampu mengeksplorasi antara kompetensi yang baru mereka peroleh dengan kompetensiyang dimiliki sebelumnya sehingga mengakibatkan ketidakpahaman atau ketidakjelasan terhadap materi pelajaran, kurang terampil dalam menyelesaikan perhitungan matematis, kurang memahami penggunaan rumus-rumus matematis dan juga faktor-faktor lainya.Kegiatan 
pembelajaran konvensional mengarah pada proses memori konsep atau prosedur yang tidak berarti, yang berakibat pada pemahaman konsep matematik sangat rendah. Karena dalam pembelajaran matematik, siswa diharuskan mengikuti aturan atau mekanisme yang berlaku sehingga mereka tidak terlibat dalam pembelajaran yang bermakna.Keterlibatan siswa dalam proses belajar akan berpengaruh pada harapan tumbuhnya proses belajar yang efektif pada diri siswa sehingga mampu meningkatkan kemampuan dan keterampilan berfikir siswa (Tanjung \& Nababan, 2018). Pengalaman penulis serta diskusi dengan beberapa pendidik matematika di SMK Kota Cirebon, kompetensi program linear merupakan kompetensi dalam matematika yang sulit dipelajari siswa. Kesulitan yang paling tak jarang ditemui pengajar terkait materiprogram linear kelas $X$ adalah kesulitan para anak didik dalam menyusun model matematikanya, atau mengganti kasus umum atau kasus pada kehidupan sehari-hari sebagai bentuk model matematika, selain dari faktor kesulitan siswa dalam pembelajaran matematika dari segi proses pembelajaran tidak efisien, lebih fokus pada staf pengajar, dan kurang memadainya penggunaan perangkat pembelajaran.

Upaya yang perlu dilakukan adalah perlu adanyatransformasi yang fundamental dalam pembelajaran matematik yaitu dengan menyusun perangkat pembelajaran yang dapat menunjang dan mengatasi kesulitan yang dihadapi siswa. Perangkat pembelajaran yang efektif dapat memberikan kontribusi yang besar dalam upaya menunjung keberhasilan siswa mengatasi kesulitannya dalam belajar, karena guru sudah mendesaian dan menyiapkan langkah, strategi yang disiapkan untuk pelaksanaan kegiatan belajar (Putra, Widyawati, Asyhari, \& Putra, 2018). Guru harus benar-benar menjadi fasilitator belajar dan lebih berkonsentrasi pada bagaimana belajar daripada apa yang harus dipelajari, artinya mereka harus menyediakan alat tangkap untuk siswa daripada memancing (Khatib, Sarem, \& Hamidi, 2013). Diperlukan perangkat belajar dan model pembelajaran yang efektif untuk mewujudkan keterlibatan siswa dalam belajar. Model pembelajaran yang dipakai oleh seorang guru sangat berpengaruh dalam keaktifan anak didik di kelas (Panggabean, 2013). Model yang efektif untuk memudahkan siswa dalam belajar adalah dengan menggunakan penyelenggara tingkat lanjut (advance organizer), dikembangkan oleh Ausubel (1978) advance organizer adalah implikasi praktis dariteoribelajar verbal bermakna. Kirkman \& Shaw, (1997) mendefinisikan advance organizer ialah program dalam belajar yang bergunauntuk memperkuat pondasi keaktifan siswa dengan mengkaji konsep dan informasi serta bagaimana mengatur dan memahami konteks dengan benar. Model advance organizer merupakan metode pembelajaran dalam upaya mendapatkan informasi dan pengalaman belajar baru terkait dengan 
penggunaan kemampuan yang telah diperoleh sebelumnya dalam proses belajar (Rahayu \& Widodo, 2010). Struktur konseptual pengetahuan yang dimiliki berdasarkan pengembangan berbasis pengetahuan, kerangka pembuatan sistem terstruktur dalam rangka pemrosesan informasi yang diperoleh siswa.

Setidaknya ada dua kelebihan yang menyertai konstruksi dan penggunaan advance organizeruntuk materi baru. Pertama, advance organizer menciptakan kondisi yang akan meperlihatkan gambaran umum tentang materi baru, dan kedua, advance organizer menciptakan hubungan kognitif antara pengetahuan yang diperoleh dan materi baru dalam kaitannya dengan konsep yang relevan sehingga akan meningkatkan kekuatan dan kemampuan belajar dari materi baru (Lin, Dwyer, \& Swain, 2006).Penerapan advance organizer menjadi kerangka isi akan menaikkan kompetensi siswa pada informasi baru lantaran kerangka yang berupa rangkuman konsep dasar pengetahuan yang dipelajari dan keterkaitan materi pada struktur kognitif siswa (Julita, 2011).

Selain penggunaan advance organizer, pendidik perlu menyampaikan pembelajaran melalui pendekatan yang tidak menambah siswa menjadi semakin takut, pendekatan yang sesuai untuk memerdekakan rasa takut siswa, yaitu mencoba membuat nyaman dan menyenangkan siswa dalam proses pembelajaran matematika adalah pendekatan humanistik yang memperlakukan manusia sebagai subjek bebas dan mandiri untuk menentukan keputusan dalam hidupnya (Sanusi, 2013). Pembelajaran humanistik mengenal manusia secara keseluruhan, tujuan belajarnya adalah memanusiakan manusia. Menurut Umar \& Redjeki (2018), pembelajaran pada pendekatan humanistik dianggap sebagai pembelajaran yang menunjukkan proses humanisasi meliputi banyak keuntungan; 1) membentuk kepribadian, hati nurani, dan mengubah perilaku yang baik; 2) membiasakan diri melakukan demokrasi, partisipasi, dialog dan hal-hal yang humanistik; 3) menciptakan rasa saling menghormati, wawasan, kebebasan berbicara terkait ide; 4) Merasa senang, antusias, berdasarkan pembelajaran. Tujuan pendekatan humanistik yaitu memotivasi danmenyertakan peran aktif siswadalam proses belajar, sehingga kemampuan matematik siswa dapat tumbuh kembang dengan baik dalam kondisi dimana mereka dapat mengeksplorasi berbagai pengetahuan yang diperolehnya (Haglund, 2004). Lebih lanjut Junaedi \& Asikin, (2012) menjabarkan mengenai konsepsi pendekatan humanistik dalam pembelajaran matematika yaitu,siswa mempunyai seperangkat konsep cara pandangan siswa dalam memecahkan masalahmatematika serta mampu memberikan saran atau solusi dalam pemecahannya; siswa memperoleh pengetahuan baru untuk dirinya; 
memperoleh pengetahuandengan memodifikasi, termasuk penciptaan, peningkatan, penambahan, penataan ulang; siswa membangun pengetahuan baru untuk diri mereka sendiri berdasarkan berbagai pengalaman. Dalam proses mendapatkan pengetahuan setiap siswatidak melihat suku, budaya dan gender.

Dalam implementasi kegiatan pembelajaran model advance organizermempunyai efek terhadap hasil belajar, seperti yang sudah diungkap oleh peneliti sebelumnya yaitu Atomatofa, (ㅁ13); Kapri, (2017); Parjayanti \& Wardono, (2013); Putra, Widyawati, Asyhari, \& Putra (2018); Shabania, Mardiati, \& Sofyan (2015). Penelitan yang sudah dilakukan oleh para penelititersebut terbukti mampu meningkatkan hasil belajar siswa, namun peneliti merasa tertarik untuk meneliti kembali dengan mempertimbangkan aspek kemampuan pemahaman relasional melalui pendekatan pembelajaran humanistik.Tujuan peneliti adalah berusaha untuk mengembangkan perangkat pembelajaran model advance organizer yang dikembangkan melalui pendekatan humanistik, menitik beratkan pada siswa sebagai objek utama pembelajaran dengan konsep memanusiakan manusia untuk meningkatkan kemampuan pemahaman relasional. Hal tersebut diperlukan untuk memenuhi hasrat untuk siap belajar dan belajar menurut kemauannya sendiri dengan mengurangi tingkat kebimbangan dan ketakutan siswa dalam pembelajaran matematika.

\section{Metode}

Penelitian pengembangan yang dikembangkan dalam penelitian model advance organizermelalui pendekatan humanistik untuk mengoptimalkan kemampuan pemahaman relasional. Penelitian dilakukan di salah satu SMK di Kota Cirebon, dengan responden kelas eksperimen sebanyak 20 siswa dan kelas kontrol 20 siswa. Desain penelitian pengembangan mengacu pada

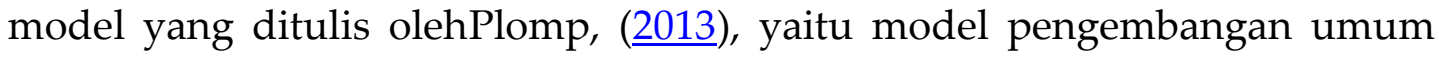
yang disempurnakan. Plomp mengusulkan 5 tahapan, (1) pemeriksaan pendahuluan, (2) desain rancangan, (3) implementasi (4) Pengujian, evaluasi dan revisi, (5) menjalankan rencana. Tahap menjalankan rencana atau biasanya disebut dengan realisasi pelaksanaan tidak dilaksanakan secara eksplisit, akan tetapi terintegrasi didalam paket penelitian, dimana pada saat perangkat pembelajaran diujicobakan di lapangan dalam lingkup objek penelitian.Desain penelitian pengembangan perangkat pembelajaran Model Plomp dipandang lebih adaptif dan fleksibel, dikarenakan pada setiap tahapannya memuat aktivitas pengembangan yang dapat disesuaikan dengan karakter penelitiannya (Rochmad, 2012). 
Kualitas hasil pengembangan model pembelajaran perlu memenuhi syarat valid, praktis dan efektif (Nieveen \& Folmer, 2014). Validitas penelitian pengembangan mencakup validitas isi danvaliditas konstruk. Lebih lanjut, Rochmad (2012) menjabarkan praktis ditunjukan jika para pakarmenegaskan bahwa menurut teorimodel dapat diimplementasikan dilapangan dan tingkat pelaksanaannya minimal dalam kategori "baik." Efektif indikatornya adalah implementasi model dapat diidentifikasi dari faktor - faktor peningkatan hasil belajar siswa; kegiatan siswa dalam proses belajar; dan kemampuan siswa dalam matematik.

Alat penghimpunan data dalam penelitian yang digunakan adalah lembar observasi, kegiatan/ aktifitas siswa, angket motivasi siswa dan guru, lembar verifikasi bahan ajar, dan alat tes. Analisis data kevalidan bahan ajar diperoleh dari data hasil verifikasi dan penilaian para pakardari setiap aspekbahan ajar yang dikembangkan selanjutnya dianalisisa berdasarkan skor rata-rata. Analisis tes kemampuan pemahaman relasional berupa pertanyaan bentukuraian, yang perlu dianalisis terlebih dahulu tingkat kesahihan, reliabilitas, daya beda, dan tingkat kesukaran soal. Data motivasi dianalisis dengan menggunakan skala Likert.Analisis keaktifan digunakan untuk memperoleh data yang dapat memberikan gambaran keaktifan siswa dalam proses pembelajaran model advance organizer dengan pendekatan humanistik materi program linear kelas $X$. Data respon siswa terkait proses pembelajaran dan respon guru terhadap bahan ajar digunakan untuk menganalisa kepraktisan. Analisis respons siswa terkait jalannya proses belajar yang digunakan yaitu analisis persentase. Pedoman penilaian (rubrik) respon guru digunakan untuk menganalisis angket respons guru. Perangkat pembelajaran dikatakan efektif, jika minimal mencapai kategori efektif yaitu: (1) pembelajaran tuntas klasikal, (2) kemampuan pemahaman relasional siswa kelas model advance organizer melalui pendekatan humanistik lebih baik dibandingkan kelas ekspositori, (3) adanya pengaruh positif yang signfikan antara motivasi dan keaktifan siswa terhadap kemampuan pemahaman relasional, (4) ada peningkatan kemampuan pemahaman relasionalpada kelas eksperimen dengan hasil minimal kategori sedang.

\section{Hasil dan Pembahasan}

Mendeskrispsikan pengembangan perangkat pembelajaran yang dihasilkan dengan menggunakan model advance organnizer melalui pendekatan humanisik dalam upaya meningkatkan kemampuan pemahaman relasional adalah tujuan utama penelitian ini. Tiga dimensi syarat kualitas hasil pengembangan perangkat pembelajaran yang akan dikembangkan seperti yang telah disampaikan Nieveen \& Folmer (2014) bahwa kevalidan, 
kepraktisan dan keefektifan. Pengembangan perangkat pembelajaran ini dikembangkan berdasarkan pendapat dari para ahli yang menyatakan bahwa pendekatan humanistik menjadikan salah satu pendekatan yang cukup efektif berfokus pada siswa membantu perkembangan siswa secara utuh melalui atensi terhadap psikologis,kejiwaan, akhlak, seni, emosi, ragadan pertumbuhan sosial, partisipatif dan lebih menyenangkan serta pengembanganpemikiran yang ilmiah, penalaran, keterampilan pemecahan masalah, dan keterampilan komunikasi (Dwijayanti, 2014; Junaedi \& Asikin, 2012; Muniroh, 2011).

Kombinasi model pembelajaran advance organizer degan pendekatan humanistik tercatat sebagai kesatuan yang saling melengkapi satu sama lain.Sintaks model pembelajaran advance organizer yang digabungkan dengan pendekatan humanistik dapat dilhat pada tabel 1.

Tabel 1. Sintaks Pembelajaran Model Advance organizer

\begin{tabular}{|c|c|c|c|}
\hline Tahapan & $\begin{array}{l}\text { Model Advance } \\
\text { orgaizer }\end{array}$ & $\begin{array}{l}\text { Inkuiri kombinasi } \\
\mathrm{AO}\end{array}$ & $\begin{array}{l}\text { Model AO dengan } \\
\text { pendekatan humanistik }\end{array}$ \\
\hline $\begin{array}{l}\text { Tahap Pertama } \\
\text { Presentasi } \\
\text { Advance } \\
\text { organizer }\end{array}$ & $\begin{array}{l}\text { Mengklarifikasi } \\
\text { tujuan-tujuan } \\
\text { pembelajaran } \\
\text { Menyajikan organizer: } \\
\text { Mengidentifikasi } \\
\text { karakteristik- } \\
\text { karakteristik yang } \\
\text { konklusif, memberi } \\
\text { contoh-contoh, } \\
\text { menyajikan konteks,mengulang. } \\
\text { Mendorong kesadaran } \\
\text { pengetahuan dan } \\
\text { pengalaman siswa }\end{array}$ & $\begin{array}{l}\text { Guru menjelaskan } \\
\text { tujuan dari } \\
\text { pelajaran, } \\
\text { mempresentasikan } \\
\text { / memberikan AO } \\
\text { Fase Orientasi } \\
\text { Guru } \\
\text { membangkitkan } \\
\text { rasa ingin tahu } \\
\text { tentang a } \\
\text { topik melalui } \\
\text { pernyataan } \\
\text { masalah }\end{array}$ & $\begin{array}{l}\text { Menginterpretasikan tujuan } \\
\text { pembelajaran, } \\
\text { menyampaikan } \\
\text { Mengidentifikasi } \\
\text { kemampuan awal (entri } \\
\text { behvior) siswa dengan } \\
\text { mendorong dan } \\
\text { memotivasi siswa untuk } \\
\text { sadar dan terlibat aktif } \\
\text { dalam pembelajaran. } \\
\text { Membangkitkan gairah } \\
\text { belajar rasa ingin tau } \\
\text { terhadap suatu topik } \\
\text { sehingga siswa secara aktif } \\
\text { siap untuk belajar. }\end{array}$ \\
\hline $\begin{array}{l}\text { Tahap Kedua } \\
\text { Presentasi } \\
\text { Tugas atau } \\
\text { Materi } \\
\text { Pembelajaran }\end{array}$ & $\begin{array}{l}\text { Menyajikan materi } \\
\text { Mempertahankan } \\
\text { perhatian } \\
\text { Membuat tahapan - } \\
\text { tahapan materi } \\
\text { pembelajaran yang } \\
\text { sistematis dan jelas }\end{array}$ & $\begin{array}{l}\text { Siswa dalam } \\
\text { kelompok } \\
\text { merumuskan } \\
\text { masalah } \\
\text { dan hipotesis }\end{array}$ & $\begin{array}{l}\text { Merancang fasilitas belajar } \\
\text { seperti lingkungan dan } \\
\text { media pembelajaran agar } \\
\text { siswa tetap fokus perhatian } \\
\text { mereka dalam upaya } \\
\text { menemukan suatu makna } \\
\text { dalam belajar }\end{array}$ \\
\hline $\begin{array}{l}\text { Tahap Ketiga: } \\
\text { Memperkuat } \\
\text { Pengolahan } \\
\text { Kognitif }\end{array}$ & $\begin{array}{l}\text { Mengembangkan } \\
\text { penyesuaian integratif } \\
\text { dan penerimaan } \\
\text { pembelajaran } \\
\text { aktif,mendapatkan } \\
\text { pendekatan kritis }\end{array}$ & $\begin{array}{l}\text { Siswa dalam } \\
\text { eksplorasi desain } \\
\text { kelompok atau } \\
\text { bereksperimen, } \\
\text { mengumpulkan }\end{array}$ & 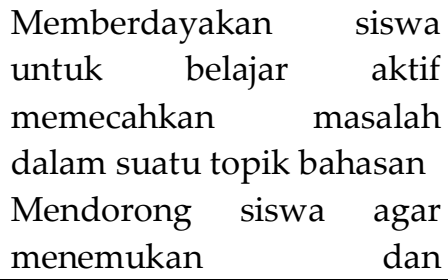 \\
\hline
\end{tabular}




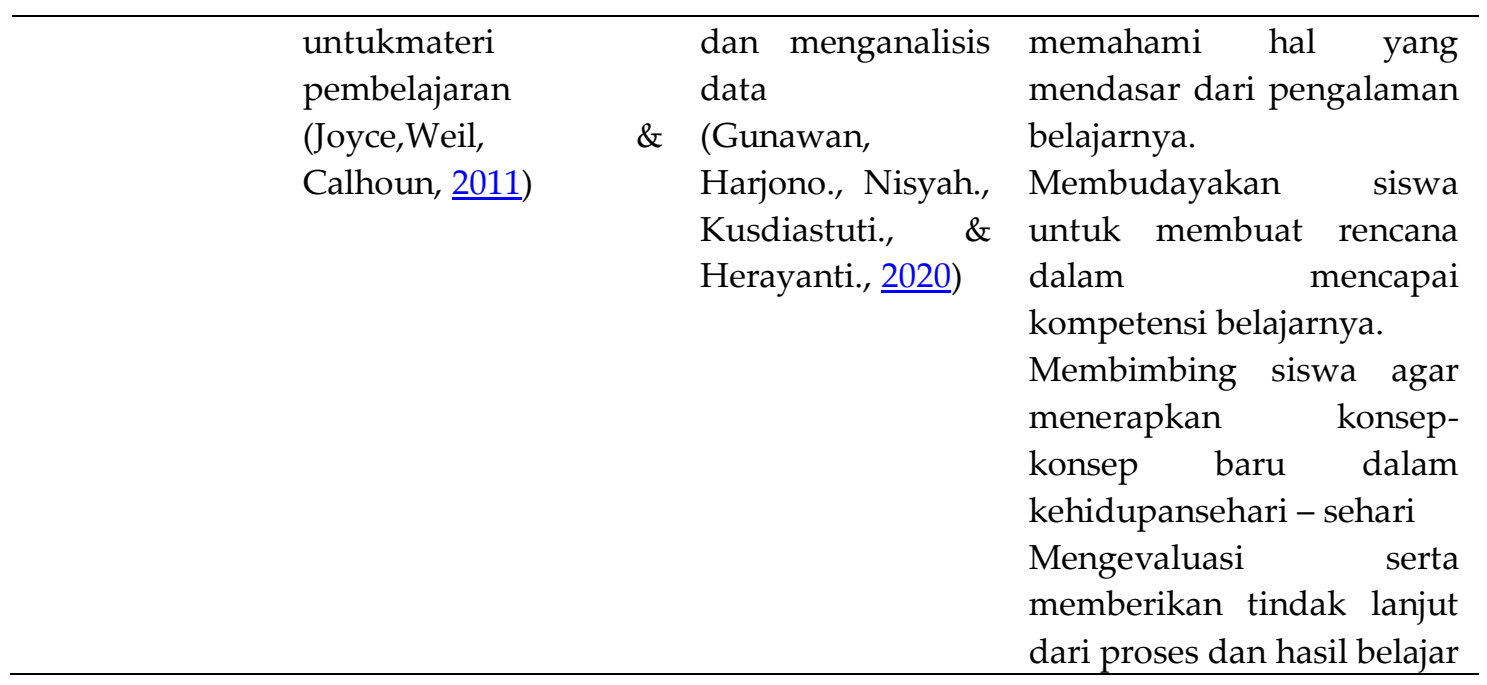

Ada tiga fase dalam advance organizer yang masing - masing dijabarkan dalam buku Joyce, Weil, \& Calhoun (2011), fase presentasi AO, fase presentasi tugas, dan fase pengolahan kognitif. Tiap fase mempunyai langkah - langkah dalam proses pembelajarannya. Kombinasi model pembelajaran inkuiri dengan advance organizeryang disampaikan Gunawan, Harjono, Nisyah, Kusdiastuti, \& Herayanti (2020), keefektifan model pembelajaran ikuiri berlangsung dengan tahapan-tahapan diskusi. Dalam sintaksis siswa membahas informasi yang diperoleh pada proses sebelumnya kemudian mereka menerapkan tahapan pemecahan masalah ke dalam pembahasantopik. Kemampuan dalam memahami, menerapkan, menganalisis dan mengevaluasi, serta langkah-langkahnya berlaku untuk semua tahapan pemecahan masalah secara bersamaan dalam proses pembahasannya. Advance organizer dengan pendekatan humanistik dalam tiga tahapan AO mengarahkan siswa untuk memahami hal yang mendasar dari pengalaman belajarnya dan siswa tetap fokus perhatian mereka dalam upaya menemukan suatu makna dalam belajar untuk mengatasi kesulitan belajar matematika, mengurangi tingkat kecemasan dan ketakutan siswa dalam pembelajaran maupun pada saat evalusai matematika dilakukan.

Salah satu kriteria utama untuk menentukan dipakai tidaknya suatu perangkat pembelajaran adalah hasil validasi oleh ahli. Validasi ahli ini dilakukan untuk melihat validitas isi dari prototype I. Validator yang melakukan validasi perangkat pembelajaran yang dikembangkan terdiri 5 orang ahli yang sesuai dengan bidangnya. Data hasil penilaian para ahli untuk setiap aspek dari setiap perangkat yang dikembangkan dianalisis berdasarkan rerata skor. Rerata skor penilaian validator dihitung dengan cara rata-rata jumlah skor perangkat pembelajaran dibagi dengan banyaknya aspek penilaian perangkat pembelajaran (Hobri, 2010). 
Deskripsi nilai rata-rata skor dari masing-masing perangkat pembelajaran (Va) ini dirujuk pada interval penentuan kriteria kevalidan perangkat pembelajaran, dapat dilihat pada tabel 2.

Tabel 2. Kriteria Penilaian Validator terhadap Bahan Ajar dan Perangkat Pembelajaran

\begin{tabular}{cc}
\hline Interval & Klasifikasi \\
\hline $1,0<V a \leq 1,8$ & Tidak baik \\
$1,8<V a \leq 2,6$ & Kurang baik \\
$2,6<V a \leq 3,4$ & Cukup baik \\
$3,4<V a \leq 4,2$ & Baik \\
$4,2<V a \leq 5,0$ & Sangat baik \\
\hline
\end{tabular}

Perangkat pembelajaran dikatakan valid jika mendapat kategori penilaian baik dan sangat baik.Peneliti dibantu ahli dari kalangan akademisi bidang matematika dan rekan sejawat (guru pengajar) matapelajaran matematika di sekolah untuk menjadi validator perangkat pembelajaran yang terdiri dari lima orang. Saat verifikasi pertama, semua verifikator akan memberikan masukan, sehingga perangkat pembelajaran yang dikembangkan perlu diperbaiki. Peneliti menganalisis berdasarkan semua verivikator yang valid untuk melakukan revisi. Perangkat hasil perbaikan akan dikembalikan ke validator untuk di evaluasi ulang, jika tidak valid akan dimodifikasi kembali hingga didapatkan perangkat pembelajaran yang valid dari pakar dan draft 2 terbentuk. Pada saat proses validasi peneliti memperoleh beberapa masukan dan catatan dari validator yaitu: Pemilihan kata pada sintak sebaiknya menggunakan istilah yang berbeda dari sintak yang sudah ada, tidak boleh menimbulkan multi tafsir terhadap sintak yang dimodifikasi. Tabel 3 menunjukkan hasil evaluasi keseluruhan yang dilakukan oleh validator pengembang.

Tabel 3.Validitas Perangkat Pembelajaran

\begin{tabular}{|c|c|c|c|c|c|c|c|c|}
\hline \multirow[t]{2}{*}{ No } & \multirow[b]{2}{*}{ Perangkat } & \multicolumn{5}{|c|}{ Nilai rata-rata } & \multirow{2}{*}{$\begin{array}{l}\text { Rata } \\
\text {-rata }\end{array}$} & \multirow[b]{2}{*}{ Kriteria } \\
\hline & & Val. 1 & Val. 2 & Val. 3 & Val. 4 & Val. 5 & & \\
\hline 1 & Silabus & 4,78 & 4,56 & 3,44 & 4,00 & 4,61 & 4,28 & SB \\
\hline 2 & $\mathrm{RPP}$ & 4,63 & 4,32 & 3,45 & 4,05 & 4,58 & 4,21 & SB \\
\hline 3 & LKS & 4,75 & 4,25 & 3,43 & 4,00 & 4,70 & 4,23 & SB \\
\hline 4 & $\begin{array}{l}\text { Buku } \\
\text { Siswa }\end{array}$ & 4,28 & 3,56 & 2,83 & 3,56 & 4,06 & 3,66 & B \\
\hline 5 & TKPR & 4,50 & 4,20 & 3,40 & 4,10 & 4,00 & 4,04 & B \\
\hline
\end{tabular}

Tabel 3 menunjukan bahwa hasil penilaian pengembangan silabus yang sudah dilakukan oleh lima validator mempunyai rata-rata 4,28 sehingga dapat dikatakan silabus sangat baik. Hal ini dapat diterangkan bahwa dalam pengembangan silabus penilaian masing-masing validator 
sependapat terkait aspek atau unsur penilaian yang termaktub dalam silabus dengan demikian silabus yang dikembangkan adalah valid.Dalam penerapan pada pembelajaran, silabus diuraikan dalam rencana proses pembelajaran yang akan dilaksanakan dan selanjutnya dievaluasi, serta ditindaklanjuti. PentingnyaSilabus untuk dievaluasi dan dikembangkan secara bertahap adalah untuk mendapatkan ketercapaian kompetensi yang akan dicapai dalam pembelajaran serta berkelanjutan dengan mempertimbangkan berbagai aspek melalui hasil evaluasi pembelajaran, evaluasi proses (pelaksanaan pembelajaran), dan evaluasi rencana pembelajaran (Sagala, 2008).

Kesesuaian RPP dan proses pembelajaran sangatlah penting dalam membantu mencapai pengetahuan siswa (Anggraeni \& Akbar, 2018). Sebagai konteks acuan dan ketentuan dalam pengembangan proses belajar yang mengarah pada peningkatan proses hasil belajar dan dapat mempengaruhi motivasi serta sikap siswasehingga dapat membantu meningkatkan kemampuan pemahaman yang lebih dalam konteks yang harus dipelajarinya. Terkait pengembangan perangkat pembelajaran yang dikembangkan pada tabel 3, penilaian 5 validator menunjukkan rata - rata sebesar 4,21 dengan kriteria yang ditetapkan berkategori sangat baik. Sehingga dapat ditarik kesimpulkan bahwa RPP yang dikembangkan valid dan dapat diterapkan dalam kegiatan untuk pencapaian peningkatan kemampuan pemahaman relasional.

Pengembangan lembar kerja siswa yang telah dikembangan dan di validasi oleh validator memperoleh rata - rata sebesar 4,23 dalam kriteria sangat baik. Artinya LKS yang telah dikembangakan adalah valid. Menurut Anggraeni \& Akbar (2018), pengantar dan panduan terhadap penggunan LKSharus benar-benar diperhatikan, agar pada saat pembelajaran siswa tidak mengalamai kesulitan dalam penggunaannya. Ketercapaian tujuan pembelajaran pada akhirnya tercapai dengan maksimal.

Pengembangan Buku pegangan siswa yang telah di validasi secara umum tidak terdapat perbedaan sigifikan antar ke lima validator, hal ini terlihat dari hasil rata - rata penilaian mencapai 3,36 dengan kriteria baik. Maka dapat disimpulkan bahwa buku pegangan siswa yang dikembangkan valid.

Tabel 4. Angket Respon Siswa dan Guru

\begin{tabular}{lcc}
\hline \multicolumn{1}{c}{ Keterangan } & Respon guru & Respon siswa \\
\hline Rata - rata & 4,30 & 17,55 \\
Rata - rata (\%) & $86 \%$ & $87,75 \%$ \\
\hline
\end{tabular}


Analisis respons siswa dan guru digunakan dalam rangka uji kualitas pengembangan perangkat pembelajaran yaitu analisis kepraktisan. Nilai rata-rata analisis angket respons siswa terhadap pembelajaran diperoleh sebesar 17,55 atau sekitar $87,75 \%$ siswa memberikan respons yang positif terhadap proses belajar yang dikembangkan, hal ini dapat dilihat pada tabel 3, lebih dari $75 \%$ siswa memberikan respons yang positif, sehingga dapat dikatakan bahwa siswa memberikan respon yang positip dan baik dalam pembelajaran menggunakan model advance organizer dengan pendekatan humanistik pada materi program linear. Nilai rata-rata berdasarkan analisis angket respon guru terhadap perangkat yang dikembangkan sebesar 4,30 atau sekitar 86\%. Dapat dikategorikan respons guru terhadap perangkat pembelajaran termasuk kategori sangat baik.

Tabel 5. Angket Motivasi Siswa

\begin{tabular}{ccc}
\hline Jumlah skor total & Rata-rata & Kategori \\
\hline 82,97 & 4,148 & Baik \\
\hline
\end{tabular}

Hasil angket motivasi siswa maka berdasarkan data hasil perhitungan yang diperoleh nilai persentase rata-rata dari semua pernyataan adalah 4,148. Berdasarkan kriteria, maka disimpulkan bahwa motivasi belajar siswa pada pembelajaran mencapai kategori baik. Dengan demikian pada saat proses belajar berlangsung hampir sebagian besar siswa memiliki hasrat yang kuat dan keinginan besar untuk berhasil dalam belajar. Menurut Dewi, Khodijah, \& Setiawan (2020), hal itu dipengaruhi oleh motivasi yang ditumbuhkan guru terkait dengan penghargaan siswa dalam proses belajar sehingga berdampak positif dengan sebagian besar siswa memiliki respon yang positif terhadap proses belajar. Motivasi dalam proses belajar sangatlah diperlukan oleh siswa, hal ini karena siswa yang memiliki motivasi akan cendurung bersemangat mengikutiproses pembelajaran, tekun mengerjakan tugas, mampu memecahkan masalah yang diberikan oleh guru (Tegeh et al., 2019). Penghargaan dalam proses belajar memiliki peran yang besar dalam ketercapaian tujuan pembelajaran, sehingga pendidik perlu meningkatkan keterampilan nya dalam usaha memotivasi anak didiknya.

\begin{tabular}{cc}
\multicolumn{2}{c}{ Tabel 6. Pengamatan Siswa } \\
\hline Pertemuan & Rerata \\
\hline 1 & 4,128 \\
2 & 4,2 \\
3 & 4,222 \\
4 & 4,228 \\
Rerata total & 4,194 \\
\hline
\end{tabular}


Analisis data tentang keaktifan siswa menggunakan pembelajaran matematika model advance organizer dengan pendekatan humanistik diperoleh nilai rata-rata dari semua pernyataan adalah 4,194. Berdasarkan kriteria, maka disimpulkan bahwa keaktifan belajar siswa pada pembelajaran mencapai kategori sangat baik. Keaktifan ini muncul setelah keterlaksanaanya proses pembelajaran dengan menggunakan pembelajaran tersebut. Keaktifan siswa selama proses kegiatan belajar mengajar adalah salah satu indikator adanya rasa ingin tahu. Salah satu indikator keberhasilan proses pembelajaran adalah ketika keterlibatan siswa aktif didalamnya (Irsyad, Wuryandini, Yunus, \& Hadi, 2020). Keaktifan siswa saat proses pembelajaran akan menyebabkan interaksi yang tinggiantara siswa dengan gurunya sehingga akan terjadi komunikasi yang efektif.

Efektifitas penggunaan perangkat pembelajaran matematika dilihat dari nilai tes kemampuan pemahaman relasional siswa. Data uji coba tes kemampuan diperoleh dengan cara mengujikan soal essay yang telah dirancang untuk materi program linear. Analisis uji efektivitas ini dilakukan setelah semua pertemuantelah selesai dilakukan pada tahap uji lapangan. Hasil kemampuan pemahaman relasional dapat dilihat pada tabel 7.

Tabel 7. Ketuntasan Siswa

\begin{tabular}{cccc}
\hline Ketuntasan & Jumlah siswa & $\begin{array}{c}\text { Rata - rata } \\
\text { nilai }\end{array}$ & $\begin{array}{c}\text { Presentase } \\
\text { ketuntasan }\end{array}$ \\
\hline Tuntas $(\geq 75)$ & 19 & 82,89 & $95 \%$ \\
Tidak tuntas $(<75)$ & 1 & 67 & $5 \%$ \\
Jumlah & 20 & & $100 \%$ \\
\hline
\end{tabular}

Data hasil belajar kemampuan pemahaman relasional yang disajikan pada tabel 7 dapat dijelaskan bahwa dari 20 siswa yang mengikuti ujian dengan skor ketuntasan belajar minimum (SKBM) matapelajaran matematika sebesar 75, diperoleh sebanyak 19 siswa atau sekitar $95 \%$ siswa tuntas dalam pembelajaran materi program linear, sedangkan yang tidak tuntas sebanyak satu orang atau sebesar $5 \%$. Dilihat dari Rata-rata nilai siswa yang tuntas sebesar 82,89 dan yang tidak tuntas sebesar $5 \%$. Dengan demikian dapat dikatakan bahwa berdasarkan kriteria ketuntasan belajar, baik itu tuntas individu maupun tuntas klasikal terpenuhi.

Terpenuhi ketuntasan belajar individual maupun klasikal tak terlepas dari keberhasilan pengembangan perangkat pembelajaran yang cukup efektif sehingga dapat layak untuk diterapkan. Ketercapaian pengembangan perangakat pembelajaran matematika model advance organizer untuk menjadikan siswa lebih aktif dan termotivasi dalam proses pembelajaran 
karena selain materi yang disajikanberkenaan lagsung dengan siswa dalam kehidupan sehari-hari model yang dikembangkan dikombinasikan dengan pendekatan humanistik yang membuat siswa nyaman dan senang dalam proses pembelajaran.

Tabel 8. Pretes dan Postes Kemampuan Pemahaman Relasional

\begin{tabular}{cllcc}
\hline \multirow{2}{*}{ No. } & \multirow{2}{*}{ Kelas } & \multirow{2}{*}{ N } & \multicolumn{2}{c}{ Rata - rata } \\
\cline { 4 - 5 } & & 20 & Pretes & Postes \\
\hline 1 & Eksperimen & 20,75 & 82,10 \\
2 & Kontrol & 20 & 32,00 & 74,65 \\
\hline
\end{tabular}

Rata-rata hasil belajar siswa kelas eksperimen yaitu kelas yang diberi perlakuan model pembelajaran advance organizer dengan pendekatan humanistik terbukti lebih baik daripada kelas pengamatan (Control). Siswa kelas eksperimen memperoleh nila rerata sebesar 82,10 $\geq 74,65$ dari kelas kontrol. Hasil yang sama pernah dilakukan Atomatofa (2013), murid yang diajar menggunakan advance organizer dalam menaikkan pemahaman dan retensi konsep ilmiah lebih baik dibandingkan dengan siswa yang hanya diajar tanpa advance organizer. Berdasarkan nilai hasil pretes dan postes KPR kelas uji coba perangkat dilakukan uji Normalitas Gain (g) untuk mengetahui kriteria peningkatan KPR siswa. Rata-rata nilai KPR yang diukur berdasarkan hasil pretes sebesar 32,75. Rata-rata nilai KPR yang diukur berdasarkan hasil postes sebesar 82,10 dengan nilai tertinggi 100. Sehingga rata-rata klasikal yang diperoleh dari uji nilai Normalitas Gain sebesar 0,73 yang berarti tafsiran peningkatan KPR yang terjadi termasuk kategori tinggi. Terjadi peningkatan hasil belajar siswa dalam kelas eksperimen ini pula diungkap oleh Bely, Bahri, \& Mustari (2019), peningkatan hasil pembelajaran matematika anak didik yang diberi perlakuan melalui pembelajaran advance organizer relatif signifikan. Sedangkan Putra, Widyawati, Asyhari, \& Putra, (2018) menyimpulkan bahwa terdapat dampak Advance Organizer terhadap kemampuan komunikasi matematissiswa. Pembelajaran matematika melalui Advance organizer, meningkatkan kemampuan penalaran matematis siswa daripada menggunakan pembelajaran matematika konvensional (Parjayanti \& Wardono, 2013).

Data tentang motivasi siswa terhadap pembelajaran matematika diambil dari lembar angket motivasi siswa dan data aktivitas diambil dari hasil observasi yang dicatat dalam tabel observasi. Sedangkan data Kemampuan pemahaman relasional diambil melalui tes hasil belajar KPR yang dilaksanakan pada akhir pertemuan. Analisis uji pengaruh motivasi terhadap kemampuan pemahaman relasional, berdasarkan hasil uji pengaruh diperoleh terjadi adalah $0,670=67 \%$. Kemampuan pemahaman relasionaldipengaruhi motivasi siswa $67 \%$ dan $33 \%$ dipengaruhi oleh faktor lain. Hal ini juga di sampaikan 
oleh Putra, Widyawati, Asyhari, \& Putra, (2018), dalam penelitiannya terdapat pengaruh motivasi terhadap hasil belajar siswa dalam proses belajar menggunakan model pembelajaran advance organizer.

Uji pengaruh keaktifan terhadap kemampuan pemahaman relasional, Besarnya pengaruh keaktifan terhadap kemampuan pemahaman relasionaldidapat $R_{\text {square }}=0,723=72,3 \%$. Dapat dinyatakan bahwa kemampuan pemahaman relasional memperoleh pengaruh dari keaktifan siswa sebesar $72,3 \%$ dan $27,7 \%$ faktor lain yang mempengaruhi.

Uji pengaruh motivasi dan keaktifan terhadap kemampuan pemahaman relasional mempunyai pengaruh yang signifikan terhadap motivasi dan aktivitas siswa didik terhadap hasil belajar kemampuan pemahaman relasional. Sedangkan untuk mengetahui besarnya pengaruh motivasi dan kepositifan terhadap KPR diperoleh nilai $\mathrm{R}$ Square $=0,780$ yang artinya gabungan pengaruh variabel motivasi dan kepositifan terhadap variabel KPR sebesar $78 \%$, dan sisanya sebesar $22 \%$ ditentukan oleh faktor lain.

\section{Simpulan}

Pengembangan perangkat dinyatakan valid berdasarkan penilaian uji perangkat yang telah di validasi berdasarkan tim pakar \& rekan sejawat. Perangkat pembelajaran yang dikembangkan dapat menaikkan kemampuan pemahaman relasional, siswa memberikan respon positif, guru memberikan responnya terhadap proses pembelajaran kelas uji cobayang termasuk pada kategori baik sehingga dapat dikatakan bahwa perangkat terbukti paraktis. Terjadi peningkatan kemampuan pemahaman relasional anak didik yang relatif tinggi dalam kelas menggunakan model advance organizer dengan pendekatan humanistik pada kelas eksperimen.

\section{Daftar Pustaka}

Anggraeni, P., \& Akbar, A. (2018). Kesesuaian rencana pelaksanaan pembelajaran dan proses pembelajaran. Jurnal pesona Dasar, 6(2), 55-65.

Atomatofa, R. (2013). Effects of advanced organizers on attainment and retention of students' concept of gravity in Nigeria. International Journal of Research Studies in Educational Technology, 2(1), 1-10.

Ausubel, D. P. (1978). In defense of advance organizers: A reply to the critics. Review of Educational Research, 48(2), 251-257.

Bely, L. N., Bahri, S., \& Mustari, M. (2019). Model Pembelajaran Advance Organizer: Dampak Terhadap Hasil Belajar Kognitif Peserta Didik. Indonesian Journal of Science and Mathematics Education, 2(2), 150-161.

Corkill, A. J. (1992). Advance organizers: Facilitators of recall. Educational Psychology Review, $4(1), 33-67$.

Dewi, D. K., Khodijah, S. S., \& Setiawan, W. (2020). Analisis motivasi belajar matematika siswa 
SMA bingkai cendekia cililin berbantuan aplikasi geogebra pada materi transformasi geometri. Jurnal Pembelajaran Matematika Inovatif (JPMI), 3(1), 49-58. https://doi.org/10.22460/jpmi.v3i1.p49-58

Dwijayanti, I. (2014). Efektivitas Kelas Humanistik dalam Pembelajaran Matematika terhadap Karakteristik Siswa. AKSIOMA: Jurnal Matematika dan Pendidikan Matematika, 5(1/MARET) 67-78.

Gunawan, G., Harjono, A., Nisyah, M., Kusdiastuti, M., \& Herayanti, L. (2020). Improving students' problem-solving skills using inquiry learning model combined with advance organizer. International Journal of Instruction, 13(4), 427-442. https://doi.org/10.29333/iji.2020.13427a

Haglund, R. (2004). Using humanistic content and teaching methods to motivate students and counteract negative perceptions of mathematics. Humanistic Mathematics Network Journal, 1(27), 1-18.

Hobri. 2010. Metodologi Penelitian Pengembangan (Aplikasi pada Penelitian Pendidikan Matematika). Jember: Pena Salsabila

Irsyad, T., Wuryandini, E., Yunus, M., \& Hadi, D. P. (2020). Analisis Keaktifan Mahasiswa dalam Proses Pembelajaran Statistika Mulitvariat. Jurnal Pendidikan Ekonomi Undiksha, 12(1), 89-96. https://doi.org/10.23887/jjpe.v12i1.24294

Jamal, F. (2014). Analisis Kesulitan Belajar Siswa Dalam Mata Pelajaran Matematika Pada Materi Peluang Kelas XI IPA SMA Muhammadiyah Meulaboh Johan Pahlawan. Jurnal MAJU (Jurnal Pendidikan Matematika), 1(1), 18-36.

Joyce, B., Weil, M., \& Calhoun, E. (2011). Models of Teaching . Pustaka Pelajar.

Julita, S. (2011). Pengaruh Model Pembelajaran Advance Organizer Terhadap Hasil Belajar Siswa di SMP Negeri 53 Palembang. Prosiding Seminar Nasional Pendidikan.

Junaedi, I., \& Asikin, M. (2012). Pengembangan Pembelajaran Matematika Humanistik untuk Meningkatkan Kemahiran Matematis. Unnes Journal of Mathematics Education Research, 1(2). 114-120.

Kapri, U. C. (2017). Effectiveness of Advance Organizer Model Over Conventional Methods of Teaching of Science At Secondary Level. International Journal of Research GRANTHAALAYAH,5(7),193-198. https://doi.org/10.29121/granthaalayah.v5.17.2017.2121

Khatib, M., Sarem, S. N., \& Hamidi, H. (2013). Humanistic Education: Concerns, Implications and Applications. Journal of Language Teaching \& Research, 4(1), 45-51.

Kinach, B. M. (2002). Understanding and Learning-to-explain by Representing Mathematics: Epistemological Dilemmas Facing Teacher Educators in the Secondary Mathematics "Methods" Course. Journal of Mathematics Teacher Education, 5(2), 153-186.

Kirkman, G., \& Shaw Jr, E. L. (1997). Effects of an Oral Advanced Organizer on Immediate and Delayed Retention.

Kovalik, C. L., \& Williams, M. A. (2011). Cartoons as advance organizers. Journal of Visual Literacy, 30(2), 39-63.

Kurniawan, A. T. H., \& Rudhito, M. A. (2016). Kemampuan Berpikir Relasional Siswa dalam Mengerjakan Soal Kontekstual dengan Pendekatan Realistik Pada Topik Fungsi Linear. Kreano, Jurnal Matematika Kreatif-Inovatif, 7(2), 136-144.

Lin, H., Dwyer, F., \& Swain, J. (2006). The Effect of Varied Cognitive Strategies Used to Complement Animated Instruction in Facilitating Achievement of Higher Order Learning Objectives. International Journal of Teaching and Learning in Higher Education, 18(3), 155-167.

Molina, M., Castro, E., \& Ambrose, R. (2005). Enriching arithmetic learning by promoting relational thinking. The International Journal of Learning, 12(5), 265-275.

Muniroh, S. (2011). Penerapan Aliran Psikologi Humanistik Dalam Proses Pembelajaran. Edukasia Islamika, 9(1), 45-61. 
Murata, A., \& Fuson, K. (2006). Teaching as assisting individual constructive paths within an interdependent class learning zone: Japanese first graders learning to add using 10 . Journal for Research in Mathematics Education, 421-456.

Nieveen, N., \& Folmer, E. (2014). Formative evaluation in educational design research. Design Research, 153, 152-169.

Panggabean, D. D. (2013). Analisis Pemahaman Konsep Awal dan Kemampuan Berpikir Kritis Bidang Studi Fisika Menggunakan Model Pembelajaran Advance Organizer dan Model Pembelajaran Direct Instruction. UNIMED.

Parjayanti, A. D., \& Wardono, W. (2013). Studi Komparasi Model Pembelajaran Antara Inkuiri dan Advance Organizer Untuk Penalaran Matematis. Kreano, Jurnal Matematika KreatifInovatif, 4(1), 64-72.

Plomp, T. (2013). Educational design research: An introduction. Educational Design Research, $11-50$.

Putra, F. G., Widyawati, S., Asyhari, A., \& Putra, R. W. Y. (2018). The Implementation of Advance Organizer Model on Mathematical Communication Skills in terms of Learning Motivation. Tadris J. Kegur. Dan Ilmu Tarb, 3(1), 41-46.

Rahayu, S., \& Widodo, A. T. (2010). Pengembangan Model Pembelajaran Advance Organizer Untuk Meningkatkan Aktivitas Dan Hasil Belajar Siswa. Jurnal Inovasi Pendidikan Kimia, $4(1), 28-35$.

Rochmad, R. (2012). Desain model pengembangan perangkat pembelajaran matematika. Kreano, Jurnal Matematika Kreatif-Inovatif, 3(1), 59-72.

Sagala, H. S. (2008). Silabus Sebagai Landasan Pelaksanaan. Jurnal Tabularasa Pps Unimed, 5(1), $11-22$.

Sanusi, U. (2013). Pembelajaran dengan Pendekatan Humanistik. Jurnal Pendidikan Agama Islam Ta'lim, 11(2), 122-131.

Shabania, N., Mardiati, Y., \& Sofyan, A. (2015). Pengaruh Pembelajaran Model Advance Organizer Terhadap Hasil Belajar Biologi Siswa Pada Konsep Protista. EDUSAINS, 7(1), 70-76.

Skemp, R. R. (1976). Relational understanding and instrumental understanding. Mathematics Teaching, 77(1), 20-26.

Tanjung, H. S., \& Nababan, S. A. (2018). Pengembangan Perangkat Pembelajaran Matematika Berorientasi Model Pembelajaran Berbasis Masalah (PBM) Untuk Meningkatkan Kemampuan Berpikir Kritis Siswa SMA Se-Kuala Nagan Raya Aceh. Genta Mulia, 9(2), 56-70.

Tegeh, M., Pratiwi, N. L. A., \& Simamora, A. H. (2019). Hubungan Antara Motivasi Belajar Dan Keaktifan Belajar Dengan Hasil Belajar Ipa Siswa Kelas V SD I Made Tegeh 1, Ni Luh Ariesti Pratiwi 2 ,Alexander Hamonangan Simamora 3. 17(2), 150-170.

Umar, M., \& Redjeki, E. S. (2018). Pendekatan humanistik dalam proses pembelajaran program pendidikan kesetaraan Paket C. Jurnal Pendidikan Nonformal, 13(2), 70-77. 